\title{
STATUS KUALITAS AIR TANAH DI KELURAHAN PEDURENAN, KECAMATAN MUSTIKAJAYA, BEKASI TIMUR
}

\author{
Maulin Inggraini ${ }^{*}$, Siti Nurfajriah, Pangeran Andareas \\ Prodi DIII Analis Kesehatan STIKes Mitra keluarga, Bekasi Timur 17113 \\ *e-mail: molinmool@gmail.com
}

\begin{abstract}
Status of Ground Water Quality in The Village of Pedurenan, Mustikajaya District, East Bekasi
\end{abstract}

\begin{abstract}
Sanitation and poor hygiene practice and unsafe drinking water contributes to $88 \%$ of childhood deaths from diarrhea in worldwide. For children who survive often suffer from diarrhea contribute to nutritional problems, preventing children to be able to achieve their maximum potential. According to the Basic Health Research (Riskesdas) in 2013, the incidence and prevalence of diarrhea for all age groups in Indonesia is 3,5\% and 7,0\%. Respectively the incidence of diarrhea is closely associated with the quality of sanitation and groundwater used by society. This study aimed to determine the quality of water used for sanitation especially groundwater, in Sub Pedurenan, District Mustikajaya, East Bekasi. Results showed that groundwater quality inspection using the Most Probable Number (MPN) in RW 02, Village and District Pedurenan Mustikajaya, there were 4 samples were negative of coliform, and 25 coliform positive samples, with the highest number of 1100 cells $/ 100 \mathrm{~mL}$. This indicates that ground water for sanitation and groundwater of sampling locations are generally contaminated by coliform bacteria.
\end{abstract}

Keywords: groun water, coliform, diarrhea, water quality, MPN

\begin{abstract}
ABSTRAK
Sanitasi dan perilaku kebersihan yang buruk serta air minum yang tidak aman berkontribusi terhadap 88\% kematian anak akibat diare di seluruh dunia. Bagi anak-anak yang bertahan hidup, seringnya menderita diare berkontribusi terhadap masalah gizi, sehingga menghalangi anak-anak untuk dapat mencapai potensi maksimal mereka. Menurut hasil Riset Kesehatan Dasar (Riskesdas) tahun 2013, insiden dan prevalensi diare untuk seluruh kelompok umur di Indonesia adalah 3,5\% dan 7,0\%. Kejadian diare sangat erat kaitannya dengan kualitas sanitasi dan air tanah yang digunakan masyarakat. Penelitian ini bertujuan untuk mengetahui kualitas air yang digunakan untuk sanitasi serta air tanah khususnya di Kelurahan Pedurenan, Kecamatan Mustikajaya, Bekasi Timur. Hasil menunjukkah bahwa pemeriksaan kualitas air tanah menggunakan metode Most Probable Number (MPN) di RW 02 Kelurahan Pedurenan dan Kecamatan Mustikajaya, terdapat 4 sampel yang negatif coliform, dan 25 sampel positif coliform, dengan jumLah tertinggi $1100 \mathrm{sel} / 100 \mathrm{~mL}$. Hal ini mengindikasikan bahwa air tanah untuk sanitasi dan air tanah di lokasi pengambilan sampel umumnya tercemar oleh bakteri coliform.
\end{abstract}

Kata Kunci: Air tanah, coliform, diarrhea, Kualitas Air, MPN

\section{PENDAHULUAN}

Sanitasi dan perilaku kebersihan yang buruk serta air minum yang tidak aman berkontribusi terhadap $88 \%$ kematian anak akibat diare di seluruh dunia (UNICEF, 2012). Bagi anak-anak yang bertahan hidup, seringnya menderita diare berkontribusi terhadap masalah gizi, sehingga menghalangi anak-anak untuk dapat mencapai potensi maksimal mereka. Kondisi ini selanjutnya menimbulkan implikasi serius terhadap kualitas sumber daya manusia dan kemampuan produktif suatu bangsa di masa yang akan datang.

Air yang digunakan untuk sanitasi dapat tercemar dengan berbagai macam pencemar, salah satunya adalah pencemar biologis. Bakteri coliform merupakan bakteri yang dikenal sebagai pencemar utama pada air. Bakteri coliform berasal dari tinja dan dapat mencemari lingkungan serta air yang dikonsumsi sehari-hari apabila tidak diproses dengan baik sebelum dikonsumsi. Bakteri coliform merupakan bakteri gram negarif, tidak membentuk spora, aerobik, dan aerobik fakultatif yang 
dapat memfermentasikan laktosa dengan mengahasilkan asam dan gas (Widiyanti dan Ristiati, 2004). Bakteri ini dapat mengakibatkan diare pada anak-anak maupun orang dewasa, oleh karena itu kehadirannya di dalam berbagai tempat mulai dari air tanah, bahan makanan ataupun bahan-bahan lain untuk keperluan manusia, tidak diharapkan dan bahkan sangat dihindari. Diare adalah penyakit dengan gejala tinja atau feses berubah menjadi cair dan penderitanya buang air besar paling sedikit tiga kali dalam 24 jam (UNICEF, 2009).

Menurut hasil Riset Kesehatan Dasar (Riskesdas) tahun 2013, insiden dan prevalensi diare untuk seluruh kelompok umur di Indonesia adalah 3,5 persen dan 7,0 persen. Lima provinsi dengan insiden maupun prevalensi diare tertinggi adalah Papua, Sulawesi Selatan, Aceh, Sulawesi Barat, dan Sulawesi Tengah. Insiden diare pada kelompok usia balita di Indonesia adalah 10,2 persen. Lima provinsi dengan insiden diare tertinggi adalah $(10,2 \%)$, Papua (9,6\%), DKI Jakarta $(8,9 \%)$, Sulawesi Selatan $(8,1 \%)$, dan Banten $(8,0 \%)$. Insiden diare dan prevalensi diare di Provinsi Jawa Barat pada tahun 2013 sebesar 2,5\% dan 4,9\%. Mengingat banyaknya insiden diare tersebut, maka penting untuk mengetahui kualitas air untuk sanitasi dan air tanah yang digunakan masyarakat.

\section{BAHAN DAN METODE}

\section{Bahan dan Alat}

Bahan yang digunakan dalam penelitian ini yaitu Air kran dan bahanbahan untuk metode MPN.

Alat yang digunakan yaitu tabung Lactose Broth Single Strength/LBSS, inkubator, dan peralatan gelas.

\section{Metode}

Pengambilan sampel dan pemeriksaan air dilaksanakan dari tanggal 4 sampai 12 Februari 2016. Pengambilan sampel dilakukan di RW 02 Kelurahan Pedurenan, Kecamatan Mustikajaya, Bekasi Timur. Pemeriksaan kualitas air dilaksanakan di Laboratorium Bakteriologi STIKes Mitra Keluarga. Sampel diambil dari air keran dan dari penampungan air. Pengambilan sampel air tanah dari keran dilakukan dengan membuka mulut keran selama 5-10 detik, kemudian ditampung pada botol kaca steril $250 \mathrm{~mL}$. Sedangkan pengambilan sampel air tanah dari bak penampungan air tanah dilakukan menggunakan botol kaca steril $250 \mathrm{~mL}$ yang telah diikat dengan tali. Pengujian coliform pada air sampel dilakukan dengan menggunakan metode MPN (Harley dan Prescott, 2002). Suspensi air sampel yang telah dihomogenkan dipindahkan sebanyak $10 \mathrm{~mL}$ ke masing-masing tabung seri pertama (3 tabung Lactose Broth Double Strength/LBDS). Suspensi air sampel dipindahkan sebanyak $1 \mathrm{~mL}$ ke masing-masing tabung seri kedua (3 tabung Lactose Broth Single Strength/LBSS). Suspensi air sampel dipindahkan sebanyak $0,1 \mathrm{~mL}$ ke masing-masing tabung seri ketiga (3 tabung Lactose Broth Single Strength/LBSS). Selanjutnya semua tabung diinkubasi pada suhu $37^{\circ} \mathrm{C}$ selama 48 jam. Tabung positif dihitung dan dicocokkan dengan tabel MPN. Analisis kualitas air akan kehadiran bakteri coliform dari uji pendugaan dilakukan sesuai standar American Public Health Association (APHA) dan dibandingkan dengan tabel MPN. Tabel tersebut berfungsi untuk memperkirakan jumlah bakteri coliform yang terdapat dalam $100 \mathrm{~mL}$ sampel air. Pembacaan hasi uji positif dilihat dari beberapa tabung uji yang menghasilkan gas dan asam (3 seri tabung pertama, kedua, dan ketiga).

\section{HASIL DAN PEMBAHASAN}

Hasil pemeriksaan bakteri coliform pada sampel air tanah di RW. 02 Kelurahan Pedurenan, Kecamatan Mustikajaya disajikan pada Tabel 1. 
Tabel 1. Hasil pemeriksaan sampel air tanah RW 02 Kelurahan Pedurenan, Kecamatan Mustikajaya

\begin{tabular}{|c|c|c|c|c|c|c|c|c|}
\hline \multirow{3}{*}{ No. } & \multirow{3}{*}{ Sampel } & \multirow{3}{*}{$\begin{array}{l}\text { Suhu } \\
\left({ }^{\circ} \mathrm{C}\right)\end{array}$} & \multirow{3}{*}{$\begin{array}{c}\mathrm{pH} \\
\text { Awal }\end{array}$} & \multicolumn{3}{|c|}{ pH Akhir } & \multirow{3}{*}{$\begin{array}{l}\text { JumLah Sel/ } 100 \\
\text { mL }\end{array}$} & \multirow{3}{*}{ Ket } \\
\hline & & & & LBDS & LBSS & LBSS & & \\
\hline & & & & & & $0,1 \mathrm{~mL}$ & & \\
\hline 1 & A & 29 & 6 & 5,6 & 6 & 6,3 & $20 \mathrm{sel} / 100 \mathrm{~mL}$ & Positif \\
\hline 2 & B & 27 & 6 & 5,2 & 5,2 & 5,7 & $43 \mathrm{sel} / 100 \mathrm{~mL}$ & Positif \\
\hline 3 & $\mathrm{C}$ & 28 & 6 & 5,7 & 5,6 & 7,1 & $93 \mathrm{sel} / 100 \mathrm{~mL}$ & Positif \\
\hline 4 & $\mathrm{D}$ & 26 & 6 & 5,1 & 5,4 & 6 & $460 \mathrm{sel} / 100 \mathrm{~mL}$ & Positif \\
\hline 5 & $\mathrm{E}$ & 28 & 6 & 5,4 & 5,1 & 5,9 & $150 \mathrm{sel} / 100 \mathrm{~mL}$ & Positif \\
\hline 6 & $\mathrm{~F}$ & 29 & 6 & 5,6 & 5,2 & 4,5 & $1100 \mathrm{sel} / 100 \mathrm{~mL}$ & Positif \\
\hline 7 & $\bar{G}$ & 28 & 6 & 5,1 & 5 & 5,2 & $1100 \mathrm{sel} / 100 \mathrm{~mL}$ & Positif \\
\hline 8 & $\mathrm{H}$ & 31 & 6 & 5,7 & 6 & 5,7 & $1100 \mathrm{sel} / 100 \mathrm{~mL}$ & Positif \\
\hline 9 & I & 31 & 6 & 5,6 & 5,6 & 5,5 & $1100 \mathrm{sel} / 100 \mathrm{~mL}$ & Positif \\
\hline 10 & $\mathrm{~J}$ & 29 & 6 & 5,5 & 5,4 & 5,9 & $240 \mathrm{sel} / 100 \mathrm{~mL}$ & Positif \\
\hline 11 & $\mathrm{~K}$ & 30 & 6 & 4,7 & 4,7 & 5,4 & $1100 \mathrm{sel} / 100 \mathrm{~mL}$ & Positif \\
\hline 12 & $\mathrm{~L}$ & 29 & 6 & 4,3 & 5,2 & 5,1 & $1100 \mathrm{sel} / 100 \mathrm{~mL}$ & Positif \\
\hline 13 & $\mathrm{M}$ & 28 & 6 & 4,6 & 5,1 & 5,3 & $1100 \mathrm{sel} / 100 \mathrm{~mL}$ & Positif \\
\hline 14 & $\mathrm{~N}$ & 31 & 6 & 5,6 & 5,3 & 4,7 & $1100 \mathrm{sel} / 100 \mathrm{~mL}$ & Positif \\
\hline 15 & $\mathrm{O}$ & 29 & 6 & 5,6 & 7 & 6,9 & $0 \mathrm{sel} / 100 \mathrm{~mL}$ & Negatif \\
\hline 16 & $\mathrm{P}$ & 33 & 6 & 5,2 & 5,3 & 6,9 & $93 \mathrm{sel} / 100 \mathrm{~mL}$ & Positif \\
\hline 17 & Q & 29 & 6 & 6,4 & 6,8 & 6,9 & $4 \mathrm{sel} / 100 \mathrm{~mL}$ & Positif \\
\hline 18 & $\mathrm{R}$ & 28 & 6 & 5,2 & 6,3 & 6,8 & $93 \mathrm{sel} / 100 \mathrm{~mL}$ & Positif \\
\hline 19 & $S$ & 30 & 6 & 5 & 5,8 & 6,2 & $460 \mathrm{sel} / 100 \mathrm{~mL}$ & Positif \\
\hline 20 & $\mathrm{~T}$ & 28 & 6 & 5 & 5,4 & 5,9 & $75 \mathrm{sel} / 100 \mathrm{~mL}$ & Positif \\
\hline 21 & $\mathrm{U}$ & 27 & 6 & 5 & 5,5 & 7 & $43 \mathrm{sel} / 100 \mathrm{~mL}$ & Positif \\
\hline 22 & $\mathrm{~V}$ & 27 & 6 & 5,6 & 7 & 7 & $4 \mathrm{sel} / 100 \mathrm{~mL}$ & Positif \\
\hline 23 & $\mathrm{~W}$ & 28 & 6 & 5,8 & 7 & 6,9 & $0 \mathrm{sel} / 100 \mathrm{~mL}$ & Negatif \\
\hline 24 & $\mathrm{X}$ & 30 & 6 & 6,2 & 6,3 & 7,1 & $9 \mathrm{sel} / 100 \mathrm{~mL}$ & Positif \\
\hline 25 & $\bar{Y}$ & 29 & 6 & 5,3 & 5,9 & 6,6 & $1100 \mathrm{sel} / 100 \mathrm{~mL}$ & Positif \\
\hline 26 & $\bar{Z}$ & 29 & 7 & 5 & 6,3 & 7,3 & $43 \mathrm{sel} / 100 \mathrm{~mL}$ & Positif \\
\hline 27 & AA & 28 & 6 & 5,3 & 6,4 & 7,2 & $43 \mathrm{sel} / 100 \mathrm{~mL}$ & Positif \\
\hline 28 & $\mathrm{BB}$ & 29 & 6 & 6,8 & 6,9 & 7 & $0 \mathrm{sel} / 100 \mathrm{~mL}$ & Negatif \\
\hline 29 & $\mathrm{CC}$ & 28 & 7 & 6,8 & 6,9 & 6,9 & $0 \mathrm{sel} / 100 \mathrm{~mL}$ & Negatif \\
\hline
\end{tabular}


Sampel air tanah diambil di RW.02

Kelurahan Pedurenan, Kecamatan Mustikajaya dilakukan untuk melihat adanya bakteri coliform. Metode yang digunakan untuk pemeriksaan bakteriologis air yaitu metode MPN tabung ganda 3-3-3 pada media LBSS dan LBDS sesuai dengan ketentuan baku mutu dari Permenkes No:416/ MENKES/Per/IX/1990 tentang per-syaratan kualitas air bersih. Permenkes tersebut menyatakan bahwa syarat-syarat mikrobiologis untuk air tanah adalam MPN coliform /100 cc sampel adalah 0. Tabel 1 menunjukkan bahwa 29 sampel air yang telah dianalisis diperoleh 25 sampel air yang positif mengandung bakteri coliform dan 4 sampel air tidak mengandung bakteri coliform. Hasil positif ditandai dengan terbentuknya gas dalam tabung durham setelah inkubasi 3 x 24 jam pada suhu $35{ }^{\circ} \mathrm{C}$. Hal ini membuktikan bahwa terjadi fermentasi laktosa oleh bakteri golongan coliform. Bakteri coliform termasuk ke dalam famili enterobacteriaceae. Bakteri enterobacteriaceae mempunyai 4 marga yaitu Escherichia, Citrobacter, Enterobacter dan Klebsiella (Harley dan Prescott, 2002).

Pemeriksaan sampel air tanah dilakukan di RW 02 yang memiliki beberapa RT, diantaranya RT 01, RT 02 , RT 03, dan RT 04. Berdasarkan hasil pengujian diperoleh bahwa seluruh sampel air RT 01 dan RT 03 mengandung bakteri coliform dengan jumLah tertinggi $1100 \mathrm{sel} /$ $100 \mathrm{~mL}$ air. Hal ini mengindikasikan bahwa air tanah telah tercemar dan tidak memenuhi standar kualitas air bersih. Air yang digunakan untuk kebutuhan seharihari seperti memasak, minum, dan mandi harus terbebas dari coliform agar aman untuk dikonsumsi. coliform merupakan bakteri yang hidup dalam usus manusia, sehingga apabila air tanah mengandung coliform merupakan indikator bahwa air tanah tersebut telah tercemar oleh tinja, hal ini mungkin dapat diakibatkan oleh kesehatan lingkungan yang kurang baik, sumber air baku yang kurang baik dan sanitasi lingkungan yang tidak baik. Bakteri coliform merupakan jenis bakteri yang umum digunakan sebagai indikator penentuan kualitas sanitasi air. Tingkat coliform yang tinggi mengakibatkan peningkatan resiko kehadiran bakteri patogen lain yang biasa hidup di dalam kotoran manusia dan hewan. Salah satu contoh bakteri patogen yang terdapat pada air terkontaminasi kotoran manusia dan hewan adalah Eschericia coli. E. coli merupakan bakteri penyebab gejala diare, demam, keram perut dan muntah - muntah (Bambang, 2014).

\section{KESIMPULAN}

Berdasarkan hasil pengujian air tanah di RW 02 Kelurahan Pedurenan dan Kecamatan Mustikajaya, terdapat 4 sampel yang negatif coliform, dan 25 sampel positif coliform, dengan jumLah tertinggi 1100 $\mathrm{sel} / 100 \mathrm{~mL}$.

\section{DAFTAR PUSTAKA}

Bambang, A. G., Fatmawali, dan N. S. Kojong. 2014. Analisis Cemaran Bakteri coliform dan Identifikasi Eschericia coli pada Air Isi Ulang dari Depot di Kota Manado. Pharmacon. 3(3): 2302 - 2493.

Harley, J. P. and L. M. Prescott. 2002. Laboratory Exercises in Microbiology. fifth edition. McGraw-Hill Companies.

Peraturan Menteri Kesehatan Republik Indonesia No. 492/MENKES/ PER/ IV/2010. 2010. Tentang Persyaratan Kualitas Air tanah.

RISKESDAS. 2013. Badan Penelitian dan Pengembangan Kesehatan Kementerian Kesehatan RI.

UNICEF. 2009. Diarrhoea: Why children are still dyingand what can be done. WHO. 
UNICEF. 2012. Air bersih, sanitasi dan kebersihan. Ringkasan Kajian.

Widiyanti, N. L. P. M dan N. P. Ristiati.

2004. Analisis Kualitatif Bakteri coliform pada Depo Air Minum Isi

Ulang di Kota Singaraja Bali. Jurnal

Ekologi Kesehatan. 3 (1): $64-73$ 